\title{
DEMARCATION OF GROUNDWATER POTENTIAL ZONES USING GEOSPATIAL TECHNOLOGY IN EDAPPADI BLOCK, SALEM DISTRICT, TAMIL NADU, INDIA
}

\section{Santhosh $\mathbf{M}^{1}$ \\ Thirukumaran $\mathrm{V}^{2+}$}

\author{
${ }^{1,2}$ Department of Geology, Government Arts College (Autonomous), India. \\ 'Email: bvmsanthosh@gmail.com Tele:+919003633823 \\ ${ }^{2}$ Email: maillumaran75@gmail.com Tele:+919600980777
}

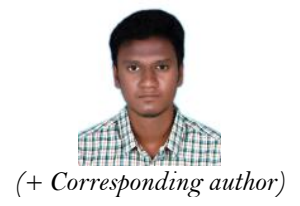

ABSTRACT

\section{Article History}

Received: 26 October 2021 Revised: 30 November 2021 Accepted: 16 December 2021 Published: 28 December 2021

\section{Keywords}

Water potential zone

GIS

Lineament density

Weightage

Edappadi

Vector overlay model.
Groundwater is one of the world's most valuable resources, which contributes $85 \%$ of drinking water supplies. It is imperative to explore ground-water zone for the utilization to the people. Edappadi block in Salem District, Tamil Nadu, is rocky terrain largely depends on groundwater for drinking and irrigation. One of the most useful tools for locating ground water potential zones is remote sensing and geographic information system (GIS). Different types of thematic maps, such as lithology, geomorphology, drainage density, slope, lineament, and land use/land cover, can be easily created by visual interpretation of IRS-1C, LISS-III data and maps are prepared using GIS. The water potential zones are determined using a rank and weightage approach. In order to demarcate the water potential zones, the vector overlay method is used. Lithology is given more weight than geomorphology, followed by lineament density, lineament frequency, lineament intersection, slope and land use/land cover. Based on the overall results, the potential zone of groundwater in the research region is divided into five groups: Excellent, Very Good, Good, Moderate, and Poor.

Contribution/Originality: The primary contribution of this research is the identification of water potential zones using remote sensing and GIS. Rank and weightage method based on field knowledge will help decision makers to plan and implement of water supply for the people.

\section{INTRODUCTION}

Groundwater has been exploited in most areas due to population growth, industrialization, and agricultural production pressures. The use of deep bore wells has resulted in a dangerously low groundwater level. India's available water supplies are not uniformly distributed. Because of differences in climatic conditions, rainfall, and topographical features, groundwater availability varies across the country. In arid and semi-arid regions around the world, groundwater is the primary source of freshwater. If the underlying aquifers are made up of hard-rock subsurface deposits, groundwater becomes even more significant. The groundwater capacity in such semi-arid hardrock aquifers is limited to shallow weathered and eroded areas (Machiwal, Rangi, \& Sharma, 2015). Groundwater has long been a significant source of water in India, accounting for $50-80 \%$ of domestic water use and $45-50 \%$ of irrigation (Mall, Gupta, Singh, Singh, \& Rathore, 2006). Hard rock formations with low porosity (less than 5\%) and very low permeability (10-1 to 10-5 m/day) cover 65 percent of India's total geographical area (Saraf \& Choudhury, 1998). Since water is an important commodity for the survival of life on Earth, and groundwater is the primary source of water, geoscientists must assess the region's water capacity, track its flow and control by geologic phenomena, and assess its quality for portability. Modern technologies including remote sensing (RS) and 
geographic information systems (GIS) have proven to be effective in mapping groundwater potential zones (Adiat, Nawawi, \& Abdullah, 2012; Deepika, Avinash, \& Jayappa, 2013; Jha, Chowdhury, Chowdary, \& Peiffer, 2007; Nag \& Ghosh, 2013). In this analysis, groundwater controlling parameters such as geology, geomorphology, slope, land use/land cover, structure, and lineament are combined, and possible water potential zones are defined using a rank and weightage process (Thirukumaran, Kumanan, \& Biswal, 2014). The porosity of the rocks determines their water-bearing qualities; however, in Study areas like the Edappadi block of Salem, where the rocks have undergone several deformation processes in addition to the inherited porosity, lithology must be given more weight. Rock types become more important in defining geomorphology in crystalline terrains. As a result, lithology received higher weightings than geomorphology, followed by fracture-related properties such as lineament density, lineament frequency, lineament intersection, and land use/land cover. Lithology received the highest weighting (10), followed by lineaments and geomorphology. Lineaments are the primary source of aquifer characteristics in crystalline terrains. As a result, the lineament-derived themes of lineament density, lineament frequency, and lineament intersection are given equal weightage and significance. A water potential zone map is developed, and the results are checked against multi-depth resistivity and water level data.

\section{STUDY AREA}

Edappadi Block is located at latitudes of $11^{\circ} 33^{\prime} 23^{\prime \prime}$ to $11^{\circ} 44^{\prime} 22^{\prime \prime}$ and longitudes of $77^{\circ} 44^{\prime} 4$ " and $77^{\circ} 53^{\prime} 31^{\prime \prime}$. The Edappadi block has an average elevation of $288 \mathrm{~m}$ (945 ft.) in MSL and is located at the nearby basin of the hill known as 'Suriya malai' (Mountain of Sun). Sankari in the south, Jalakandapuram in the north, Konganapuram in the east, and Poolampatti in the west define the study area is shown in study area map Figure 1. The Cauvery River flows 8 kilometers west of the town from north to south, and the taluk covers an area of 324 square kilometers.

\section{METHODOLOGY}

In this analysis, eight themes are chosen based on their merits about the study window. Geomorphology and lineament themes are created using IRS IC LISS III data. The drainage map is created using 1:50,000 scale toposheets from the Survey of India's 58 I series. For lithology, district resource maps published by the Geological Survey of India (scale 1:2,50,000, 1987) are used, and a slope map is created using SRTM data. From https://doi.org/10.3334/ORNLDAAC/1336, data for the land use/land cover map was downloaded. Lineament density, frequency, and intersection map are calculated using lineament map, and drainage density map is created using drainage map. Using ArcGIS 10.5, the potential zones are obtained by weighted overlay combinations depicted in Figure 2 as Methodology Flow Chart. All of the vector GIS layers from the 8 terrain systems Figures 3 to 11 are used in this method, and weightages (Wi) are assigned to each of these 8 terrain systems based on their potential influence and control over a region's water resources. Then, for each of the 8 sub-variables, scores are allocated (Sij). The sub variable scores (Sij) are then compounded by the terrain system weightage (Wi), and water potential zone weightages (Wi x Sij) are calculated for each sub variable. For instance, Wi is 10 for the lithology layer and $\mathrm{Sij}$ is 9 for the Amphibolite. As a result, the Amphibolite's final water potential weightages (Wi x Sij) are 90. (10 x 9). Water resource weightages are calculated for each sub variable of the 8 terrain structures, and the corresponding weightages are allocated to those sub-variables. The total weights of the final integrated map are calculated using this formula as the sum of the weights allocated to the various layers based on their suitability. Finally, by superimposing the block map over the groundwater potential zone map, the groundwater situation in the Study region is measured.

\section{GEOLOGY OF STUDY AREA}

The study area is significant because it is located in the transition zone between high and low-grade terrain in South India, as well as along a deep shear zone. The high-low-grade transition zone is an irregular zone that 
extends 600 kilometers from Mangalore on the west coast to Madras on the east coast of South India. Part of the Sankagiri granites forms the southern boundary and majorly covered by charnockite, granite gneiss, pegmatites. The primary sedimentary and igneous system in the study region is unlikely to survive without being heavily changed and largely obliterated.

\section{RESULT AND DISCUSSION}

\subsection{Lithology}

First, the weightages (Wi) are applied to the eight terrain parameters, as seen in Table 1, as discussed in the methodology. The lithology is given a maximum weightage of 10 in this analysis because the rock assemblage of the Edappadi block is peculiar, containing brittle charnockite, Granite Gneiss, amphibolite, and other minerals. Porosity distinguishes these rocks from one another in terms of water resources.

Secondary porosity is a key feature of crystalline aquifers, in which the reaction to shearing differs from rock to rock, affecting their water-holding ability. Amphibolite is given a higher score of 9 than Granite Gneiss based on highly foliated and weathered nature (Table 1). Charnockite, pegmatite, syenite, and granite are given 8 based on its secondary porosity. Similarly, rocks are graded based on their ability to carry water, and a weighted lithology GIS map is developed Figure 3.

\subsection{Geomorphology}

Hydro geomorphology was used by authors such as József (1999); Sankar (2002); Sikdar, Chakraborty, Adhya, and Paul (2004); Gopinath and Seralathan (2004); (Sujarose \& Krishnan, 2009); Murugesan, Krishnaraj, Kannusamy, Selvaraj, and Subramanya (2011) to delineate water potential areas. The predominant terrain in the study region is plains, as shown by Pediplain and hills. As a result, the geomorphology is given a weightage (Wi) of 9 .

Structural hills, Denudational slope, Pediplain, and Floodplain are four distinct geomorphologic units that have been defined and delineated from the study region. These geomorphic zones differ in distribution and extent from one location to another. Floodplain earned the highest ranking, followed by pediplain and then marshland Table 1. Due to their lower odds of holding water, denudational hills are given low grades. A weighted geomorphology GIS map is created Figure 4 .

\subsection{Lineament}

Joints, cracks, and faults are hydrogeological significant and may serve as portals for groundwater movement (Sankar, 2002). Lineaments can serve as a conduit for groundwater movement, resulting in increased secondary porosity and thereby serving as a groundwater prospective region. Groundwater deposition sites can also be found at the junction of lineaments. As a result, even in hilly regions with no groundwater prospects, areas with a high lineament density can have significant groundwater prospects.

Ramasamy (1987) has combined regional spatial information of transmissivity, permeability, and storage coefficient values and concluded that groundwater flow in the area south of Cauvery is controlled by folded systems, whereas groundwater flow in the northern area is controlled by fracture systems. Lineament-related features such as density, frequency, and intersection are given a weightage (Wi) value of 8 as a result.

\subsection{Lineament Density}

Ramasamy, Nagappan, and Selvakumar (2001) investigated the fracture density and its effect on groundwater in a hard rock aquifer system in central Tamil Nadu. The cumulative length of the lineaments is measured per $1 \mathrm{x} 1 \mathrm{sq} . \mathrm{km}$ grid in the current analysis to create a lineament density diagram. The calculated values are then distributed to the grid centers that corresponded to them. Per grid, the values varied from $320 \mathrm{~m}$ to $80 \mathrm{~m}$. Each class 
is given a score and the points are divided into five categories. The highest lineament density received a score of 10 and the lowest lineament density received a score of 2 . (Table 1, Figure 5).

\subsection{Lineament Frequency}

The weighted lineament frequency map is created by counting the number of lineaments per $1 \mathrm{x} 1 \mathrm{sq} . \mathrm{km}$ grid and assigning weighted values to each lineament (Table 1, Figure 6).

\subsection{Lineament Intersection}

A weighted lineament intersection map is created by counting the number of lineament intersections per $1 \mathrm{x} 1 \mathrm{sq} . \mathrm{km}$ grid and assigning weighted values to each intersection (Table 1, Figure 7).

\subsection{Slope}

The slope is important in groundwater occurrence because penetration is inversely related to the slope. A slope break (i.e., a moderate slope followed by a gentler slope) typically facilitates significant groundwater penetration. The steeper the slope, the greater the runoff, and thus the less favorable for groundwater recharge.

The slope in degrees is estimated using SRTM data. In the study area, the defined slope category ranges from $1^{\circ}$ to $9^{\circ}$ and is divided into two classes: $0^{\circ}$ to $3^{\circ}$ (gentle) and $3^{\circ} 0^{\prime} 01$ to $20^{\circ}$ (moderate). Weightage ratings are allocated, and total weighted values for each slope are determined in Table 1, and a weighted slope chart is developed Figure 8.

\subsection{Drainage Density}

Drainage channels drawn on SOI topographic maps represent pathways for surface runoff to flow downslope. The sheet wash has more surface water penetration than the channel flow. Based on a spatial intensity study of the drainage network, various drainage density zones, such as extremely high, high, moderate, medium, and very low, are created to visualize the areas of sheet flow/channel flow. More drainage lines are closer together in areas with a high drainage density, and vice versa. The prospects for groundwater in areas with high irrigation density are low since the majority of the water pumped over them after the drought is wasted as surface runoff, with no penetration to reach groundwater. Low drainage density zones, on the other hand, allow for more penetration and recharge of groundwater and thus have greater groundwater capacity (Md Surabuddin, Pandey, \& Garg, 2008). Table 1 shows the weightage scores of the total weightage for each drainage density, and a weighted drainage density chart is developed in Figure 9.

\subsection{Land Use/Land Cover}

The various land-use groups delineated include Water Bodies, Plantations, Cropland, Shrubland, Fallow Land, and Buildup Land, and traditional methods of visual representation are used to identify and understand the land use pattern of the region. Each land use and land cover group is allocated weightage scores Table 1, and weighted land use and land cover chart is created as a result Figure 10.

\subsection{Vector Overlay and Identification of Groundwater Potential Zones}

The eight Weighted GIS vector layers of different terrain parameters are simplified by dissolving with scores of different classes of each terrain parameter, and the simplified vector layers are combined using ArcGIS' analysis tool's "UNION" option. Geographical Information Systems (GIS) are used to perform a variety of basic spatial analysis procedures and may use a variety of analytical techniques. The properties of the features participating in the overlay are carried over, as seen in the example below, where layer 1 and layer 2 polygons are overlaid (using the Union tool) to construct a new polygon layer. The territories are divided where the layer 2 zone boundaries 
cross them, and new polygons are formed. Both polygons preserve their original group values as well as the overlaid polygon value. Overlay processing can be used to integrate the properties of several databases into a single one.

\subsection{Water Potential Zones}

As mentioned earlier, 8 terrain parameters with their subclasses are combined one by one, yielding 3287 polygons with scores ranging from 114 to 482 Figure 12. As seen in Table 2 the values are divided into five groups. Based on the graded scores in Table 2, the water potential map is generated by dissolving all 3287 polygons into five polygons Figure 11.

Groundwater potential zones are subsequently defined by combining all of the foregoing thematic layers based on their ranks and weightages. Five groundwater prospect zones such as (i) Excellent (ii) Very good (iii) Good (iv) Moderate and (v) Poor zones are indicated in the final output.

\subsection{Validation}

The delineated groundwater potential zone map is validated with the Isoresistivity map. The resistivity valley can be taken as high-water potential zones and similarly, the resistivity hills may be corresponding to low water potential zones.

\subsection{Iso-Resistivity Method}

Resistivity is one of the most commonly used geophysical tools for groundwater research, with the resistivity drops/changes/flats in the curves indicating the water potential region and serving as a confirmation tool (Lahcen, Gorini, Mania, Deffontaines, \& Zerouali, 2004). Since the sample area is approximately 198 square kilometers, identifying and further correlating low resistivity values is an optimal process Figure 13. Using iso resistivity values contours are drawn and analyzed.

\section{CONCLUSION}

GIS tools are used to create thematic layers relating to groundwater existence, such as geology, geomorphology, land use/land cover, lineament intersection, lineament frequency, lineament density, drainage density, and slope. Slope plays a vital role in groundwater augmentation; concentration of drainage density and lineament density also help the infiltration ability of the groundwater system.

Excellent groundwater potential zones are identified Patchy in the interior areas of the $1 \mathrm{sq} . \mathrm{km}$ study area, according to the groundwater potential zone map. The inner regions of SE and NE, which cover a total area of 31 sq. km, have very good groundwater potential zones. The highest section, which covers $127 \mathrm{sq} . \mathrm{km}$, has good groundwater potential zones. The Moderate groundwater potential zone is found in the NE, NW, and some patches in the inner section of the research region, covering $33 \mathrm{sq} . \mathrm{Km}$. The poor groundwater potential zone is primarily found in the NE and NW of the $7 \mathrm{sq}$. Km study region. The objectives of this research can be used as guidance for future artificial recharge works in the study area, ensuring long-term groundwater usage. This is an empirical method for employing Remote Sensing and GIS to explore groundwater potential zones, and it is successful in presenting possible groundwater zone sites.

The vector overlay technique is very effective in spatial modeling of identifying groundwater potential zones. This is further validated by geophysical investigations in that area. The groundwater controlling parameters like geology, geomorphology, slope, land use, and structure and lineament is integrated and probable water potential zones are identified by rank and weightage method in the present study. The highest weightage 10 is given to the lithology, followed by geomorphology. In crystalline terrains, the aquifer characters are mainly imparted by lineaments. So, the lineament derived themes, viz: the lineament density, lineament frequency, and lineament 
intersection are given importance and equal weightage. The output is validated with multi iso resistivity data and a water potential zone map is prepared.

Table-1. Weightages assigned to 8 terrain parameters.

\begin{tabular}{|c|c|c|c|c|c|c|}
\hline Si. No & Themes & \multicolumn{2}{|l|}{ Class } & $\begin{array}{l}\text { Weightage } \\
\text { (Wi) }\end{array}$ & $\begin{array}{l}\text { Score } \\
(\mathrm{Sij})\end{array}$ & $(\mathbf{W i} \times \mathbf{S i j})$ \\
\hline \multirow[t]{4}{*}{1} & Lithology & \multicolumn{2}{|c|}{$\begin{array}{l}\text { Garnet Gneiss, Granite } \\
\text { Gneiss, Meta Ultramafite }\end{array}$} & 10 & 10 & 100 \\
\hline & & \multicolumn{2}{|c|}{ Amphibolite } & 10 & 9 & 90 \\
\hline & & \multicolumn{2}{|c|}{ Charnockite, Pegmatite } & 10 & 8 & 80 \\
\hline & & \multicolumn{2}{|c|}{ Granite, Syenite } & 10 & 7 & 70 \\
\hline \multirow[t]{4}{*}{2} & Geomorphology & \multicolumn{2}{|c|}{ Flood Plain } & 9 & 10 & 90 \\
\hline & & \multicolumn{2}{|c|}{ Pediplain } & 9 & 9 & 81 \\
\hline & & \multicolumn{2}{|c|}{ Structural Hill } & 9 & 8 & 72 \\
\hline & & \multicolumn{2}{|c|}{ Denudational Hill } & 9 & 7 & 63 \\
\hline \multirow[t]{5}{*}{3} & Lineament density & Very High & $>320$ & 8 & 10 & 80 \\
\hline & & High & $240-320$ & 8 & 8 & 64 \\
\hline & & Moderate & $160-240$ & 8 & 6 & 48 \\
\hline & & Low & $80-160$ & 8 & 4 & 32 \\
\hline & & Very Low & $<80$ & 8 & 2 & 16 \\
\hline \multirow[t]{5}{*}{4} & Lineament Frequency & Very High & $>3.5$ & 8 & 10 & 80 \\
\hline & & High & $2.5-3.5$ & 8 & 8 & 64 \\
\hline & & Moderate & $1.5-2.5$ & 8 & 6 & 48 \\
\hline & & Low & $1-1.5$ & 8 & 4 & 32 \\
\hline & & Very Low & $0-1$ & 8 & 2 & 16 \\
\hline \multirow[t]{5}{*}{5} & Lineament Intersection & Very High & $>22$ & 8 & 10 & 80 \\
\hline & & High & $17-22$ & 8 & 8 & 64 \\
\hline & & Moderate & $12-17$ & 8 & 6 & 48 \\
\hline & & Low & $7-12$ & 8 & 4 & 32 \\
\hline & & Very Low & $\mathrm{O}-7$ & 8 & 2 & 16 \\
\hline \multirow[t]{2}{*}{6} & Slope & \multicolumn{2}{|c|}{ Gentle Slope } & 7 & 10 & 70 \\
\hline & & \multicolumn{2}{|c|}{ Moderate Slope } & 7 & 8 & 56 \\
\hline \multirow[t]{5}{*}{7} & Drainage Density & Very low & $<130$ & 6 & 10 & 60 \\
\hline & & Low & $130-250$ & 6 & 8 & 48 \\
\hline & & Moderate & $250-380$ & 6 & 6 & 36 \\
\hline & & High & $380-500$ & 6 & 4 & 24 \\
\hline & & Very high & $>500$ & 6 & 2 & 12 \\
\hline \multirow[t]{5}{*}{8} & Land use/Land cover & \multicolumn{2}{|c|}{ Water Bodies } & 5 & 10 & 50 \\
\hline & & \multicolumn{2}{|c|}{ Plantations, cropland } & 5 & 8 & 40 \\
\hline & & \multicolumn{2}{|c|}{ Shrubland } & 5 & 6 & 30 \\
\hline & & \multicolumn{2}{|c|}{ Fallow Land } & 5 & 4 & 20 \\
\hline & & \multicolumn{2}{|c|}{ Buildup Land } & 5 & 2 & 10 \\
\hline
\end{tabular}

Table-2. Classification of Water Potential zones.

\begin{tabular}{c|c|c}
\hline SI. No & Score & Class \\
\hline 1. & $<300$ & Poor \\
\hline 2. & $300-349$ & Medium \\
\hline 3. & $350-399$ & Good \\
\hline 4. & $400-449$ & Very Good \\
\hline 5. & $>449$ & Excellent \\
\hline
\end{tabular}




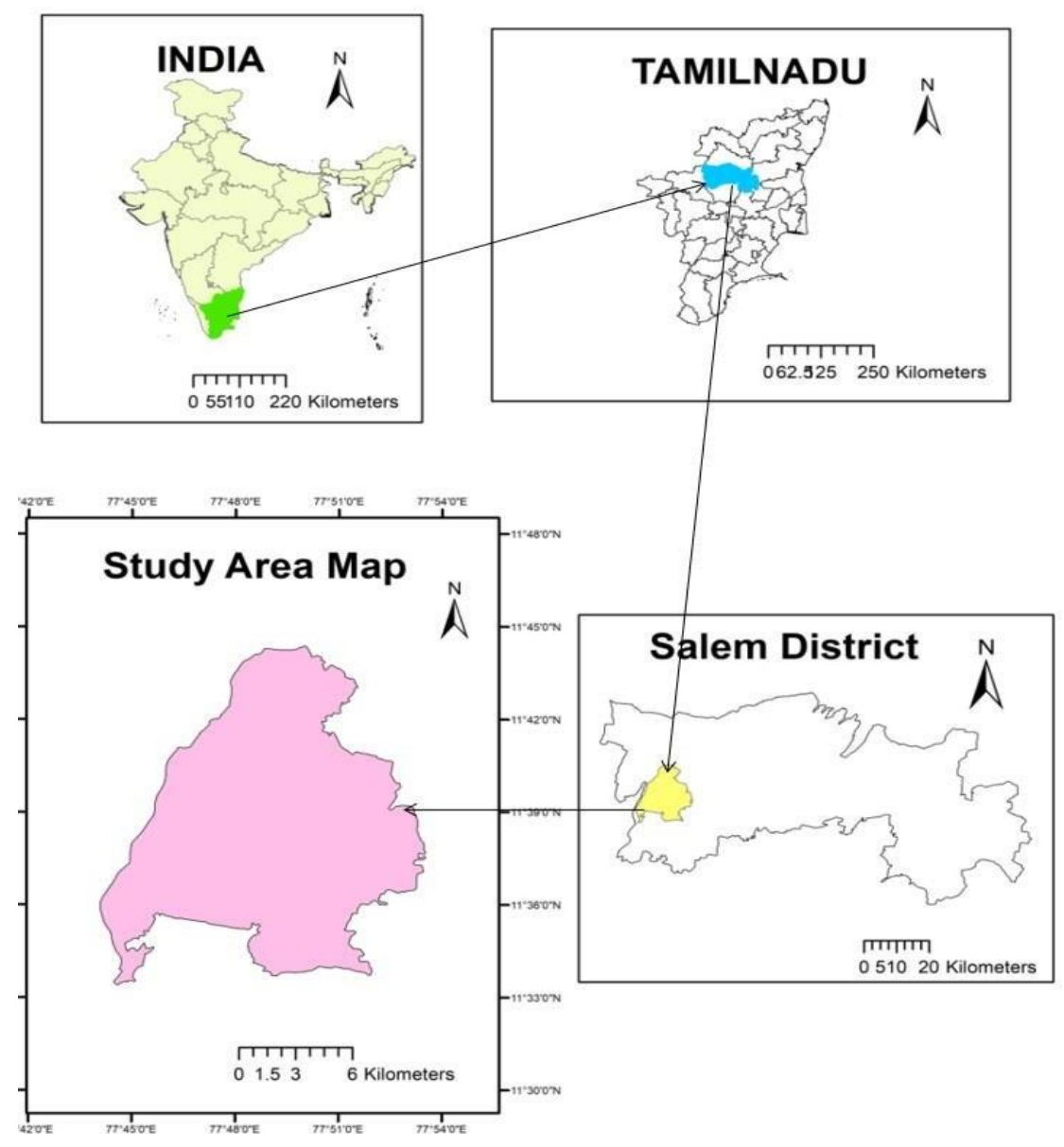

Figure-1. Study area map.

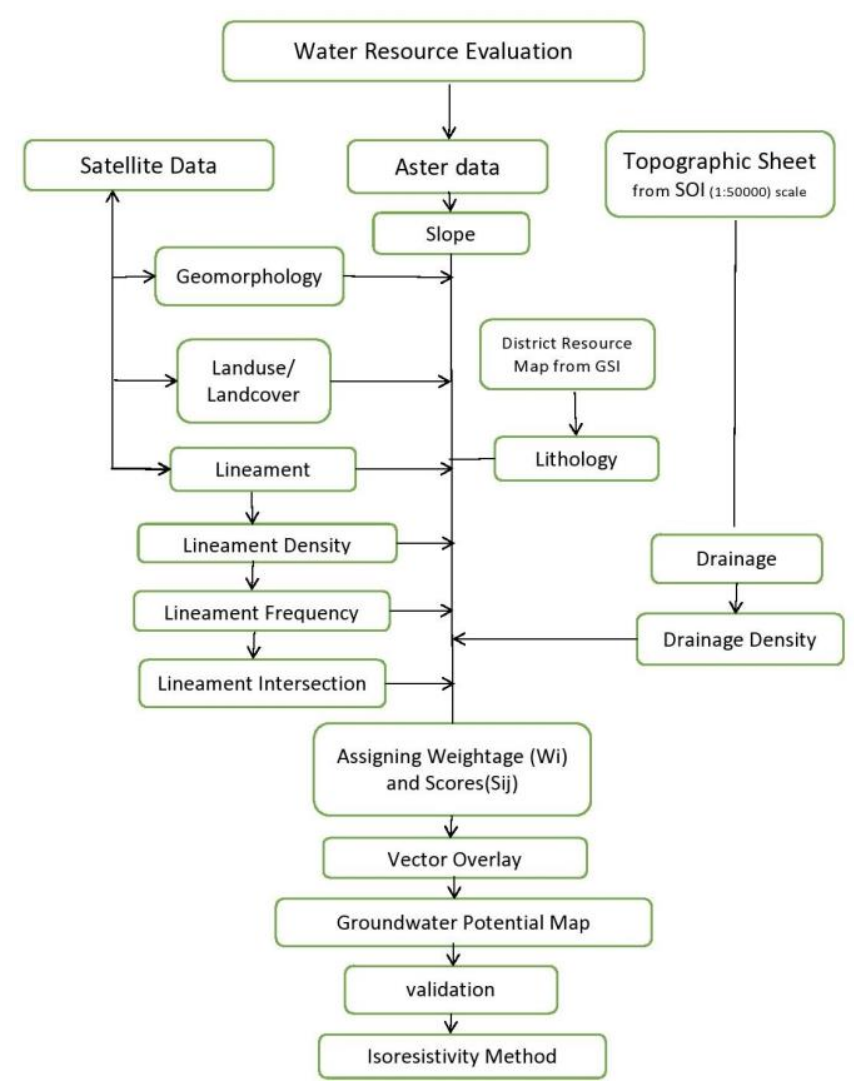

Figure-2. Methodology flow chart. 
International Journal of Geography and Geology, 2021, 10(2): 36-49
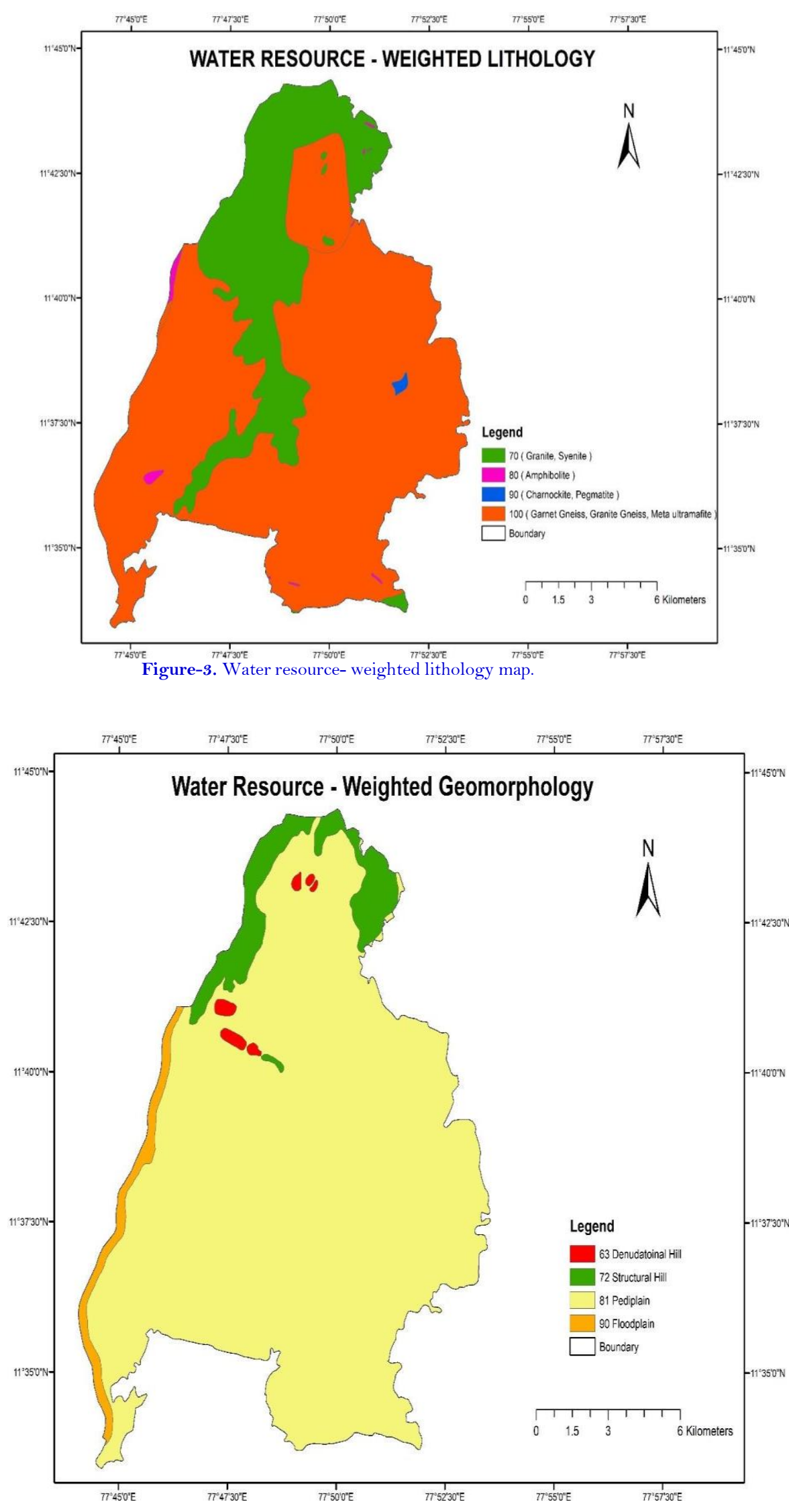

Figure-4. Water Resource- weighted geomorphology map. 

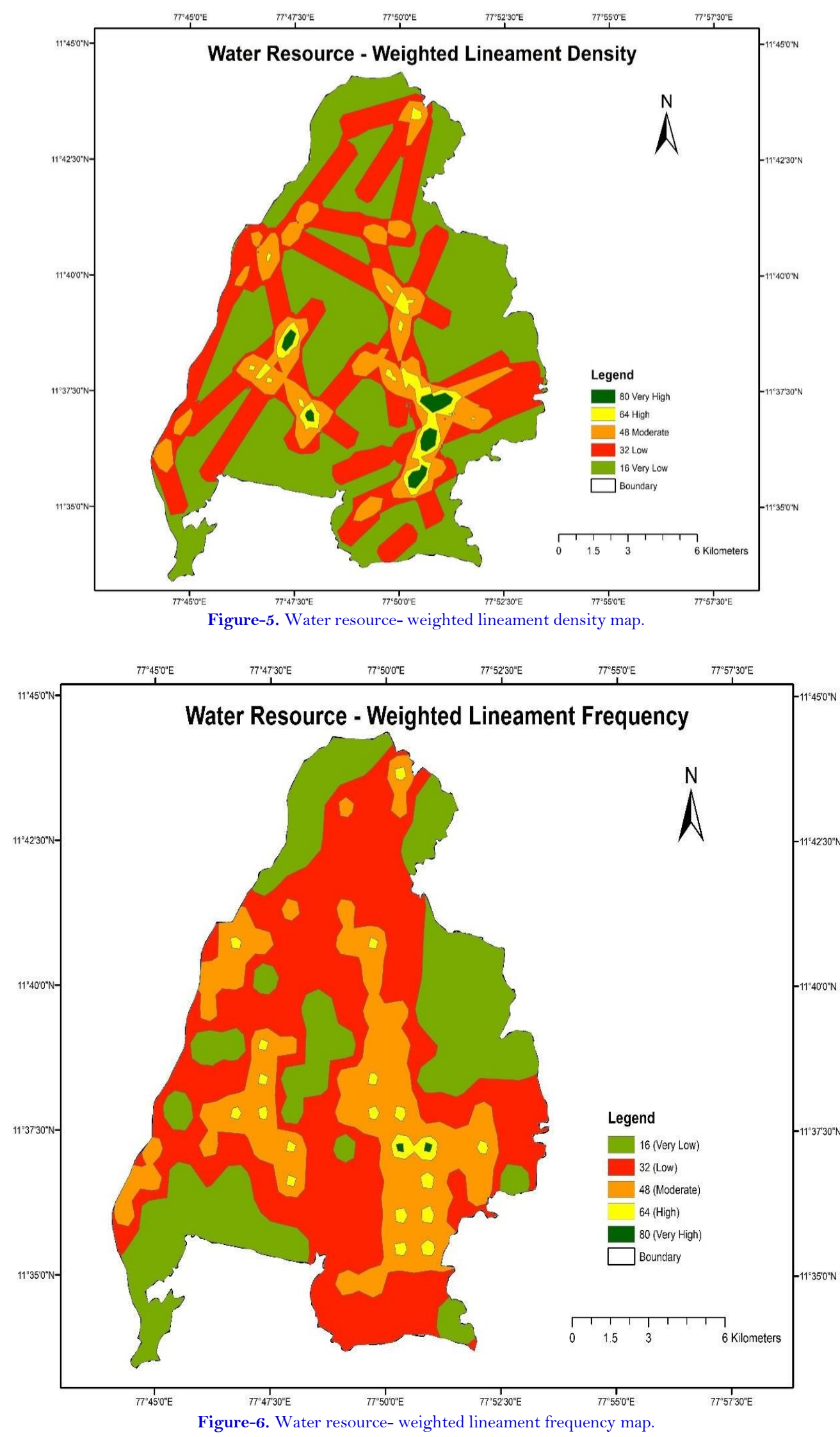
International Journal of Geography and Geology, 2021, 10(2): 36-49
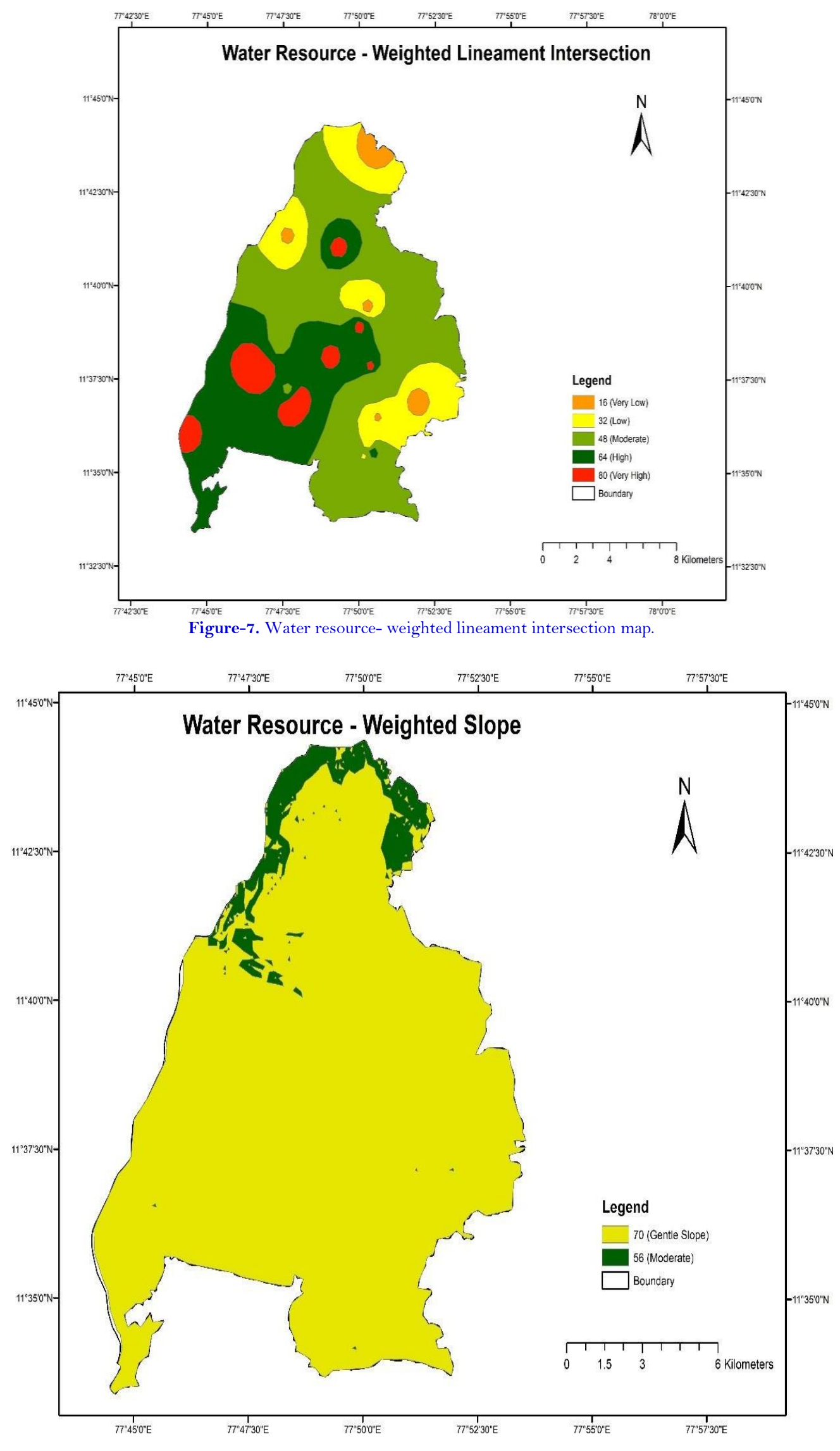

Figure-8. Water resource- weighted slope map. 

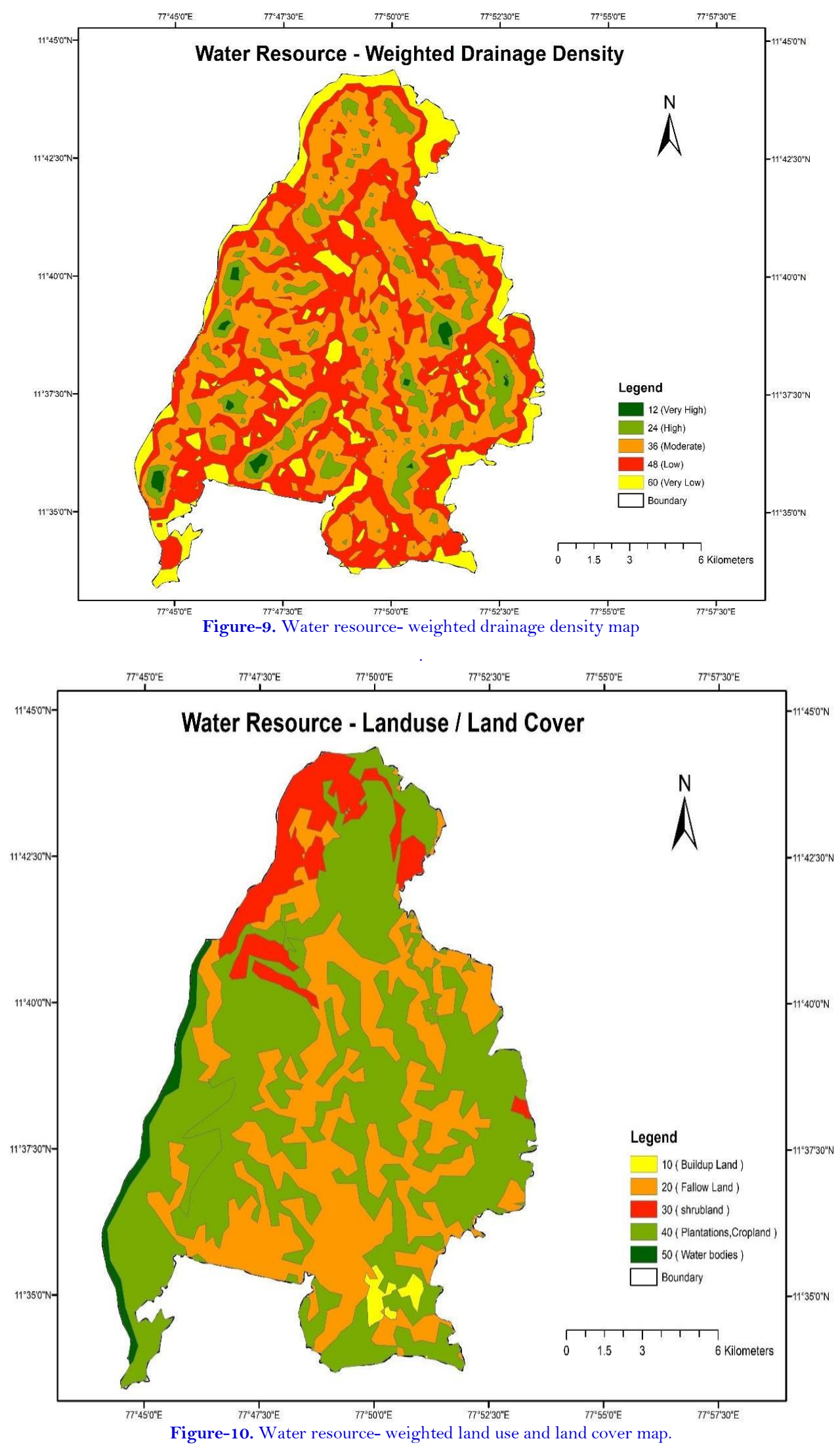


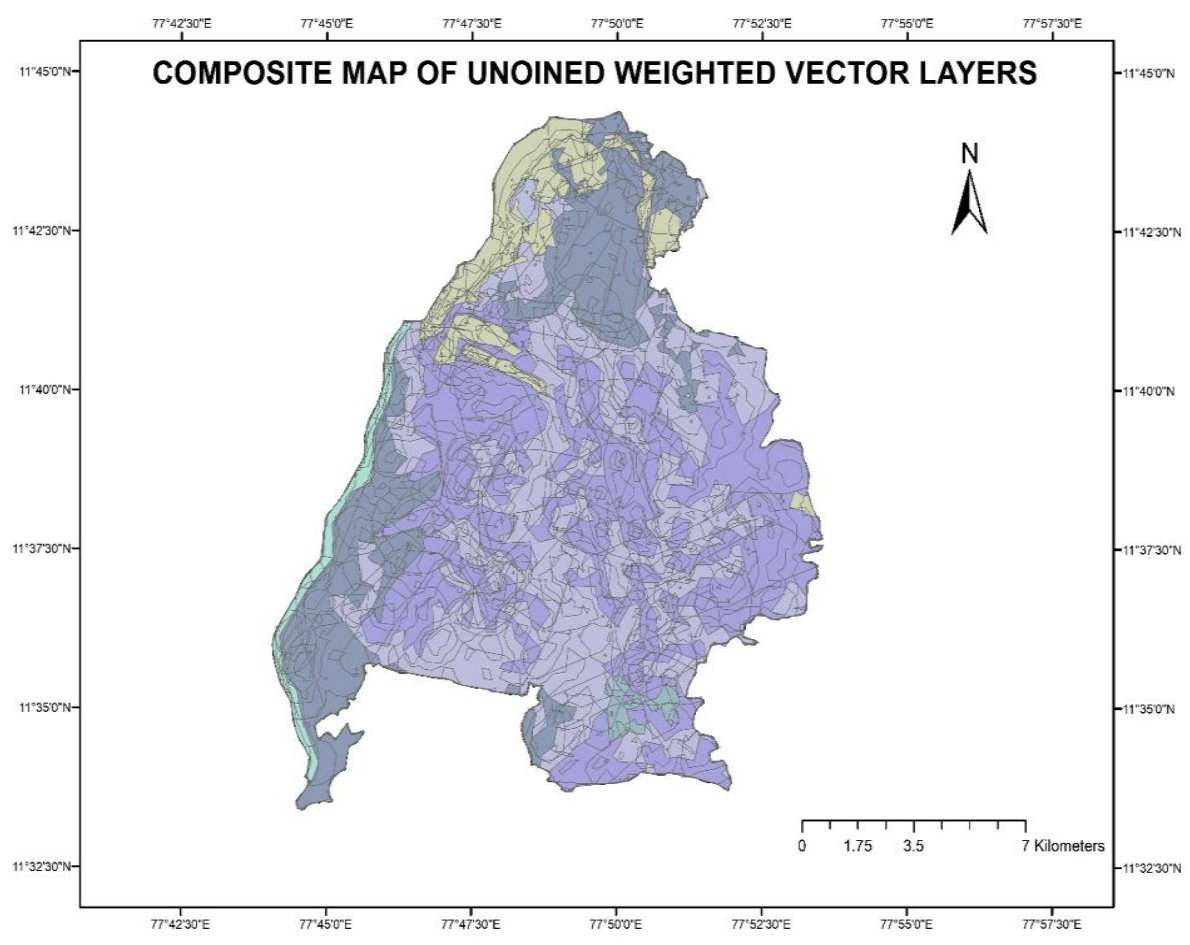

Figure-11. Composite map of weighed vector layers.

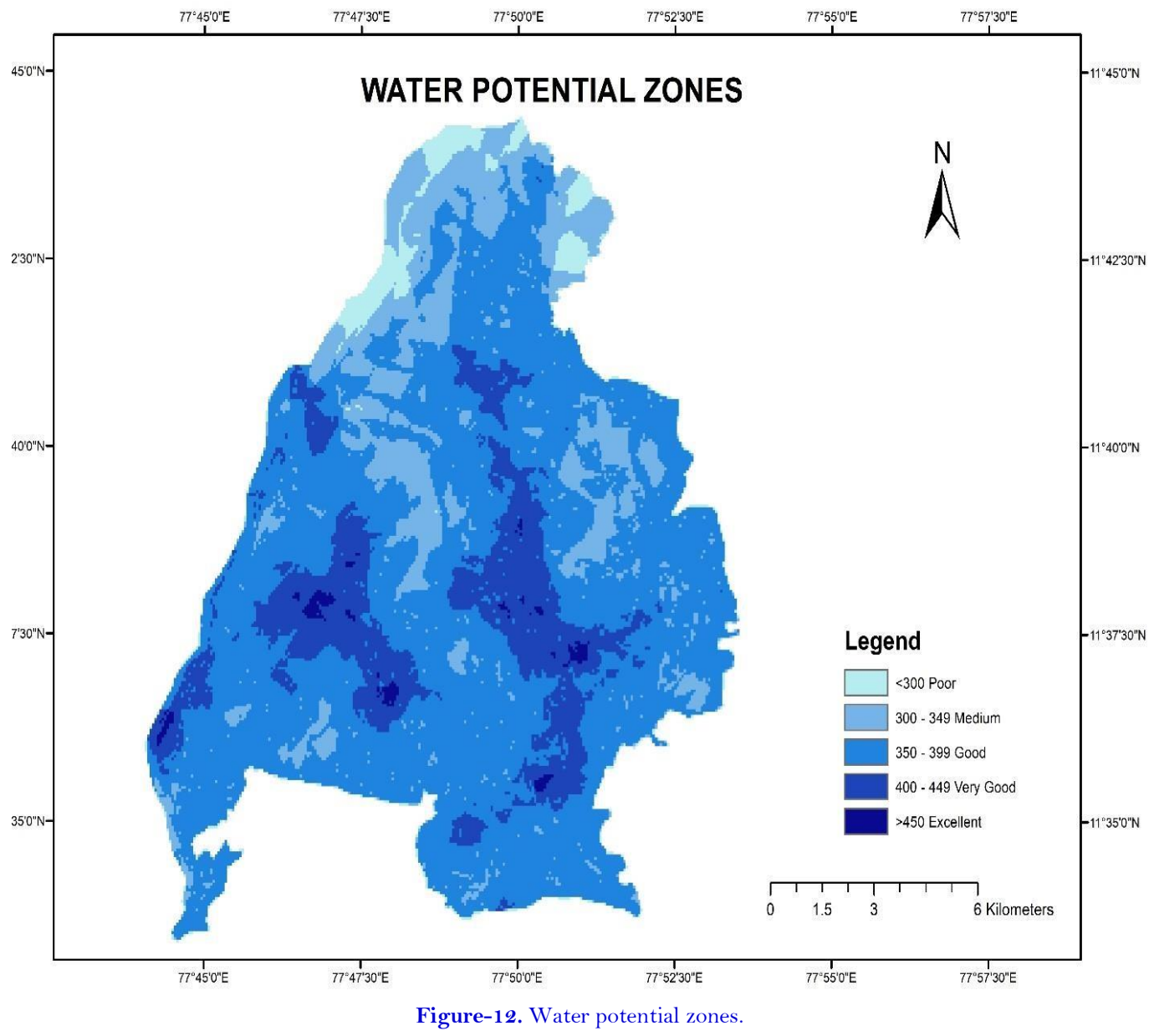




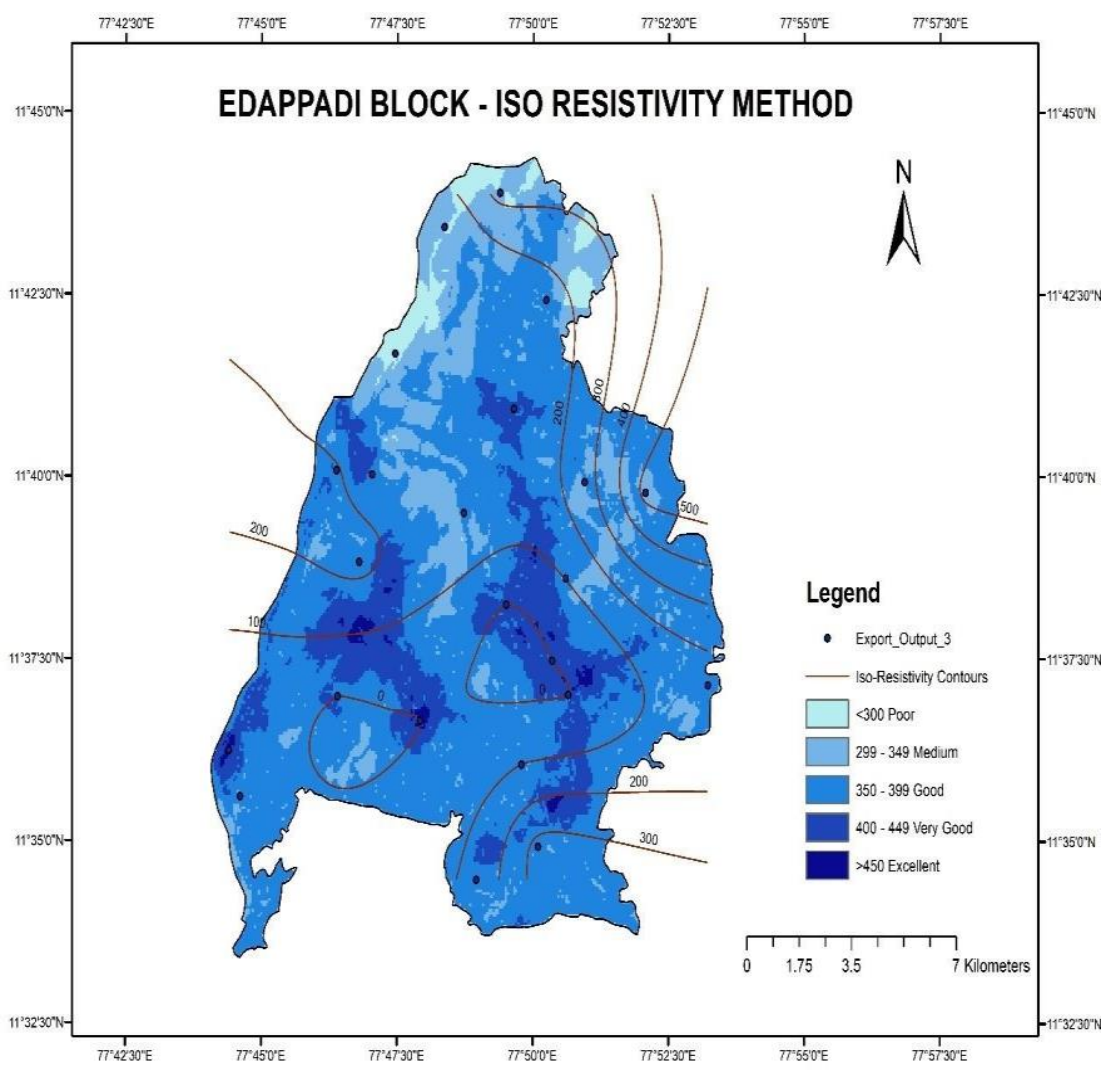

Figure-13. Validation- Isoresistivity Method.

Funding: This study received no specific financial support.

Competing Interests: The authors declare that they have no competing interests

Acknowledgement: Both authors contributed equally to the conception and design of the study.

\section{REFERENCES}

Adiat, K., Nawawi, M., \& Abdullah, K. (2012). Assessing the accuracy of GIS-based elementary multi criteria decision analysis as a spatial prediction tool-a case of predicting potential zones of sustainable groundwater resources. Journal of Hydrology, 440(2012), 75-89. Available at: http://dx.doi.org/10.1016/j.jhydrol.2012.03.028.

Deepika, B., Avinash, K., \& Jayappa, K. (2013). Integration of hydrological factors and demarcation of groundwater prospect zones: Insights from remote sensing and GIS techniques. Environmental Earth Sciences, 7O(3), 1319-1338. Available at: https://doi.org/10.1007/s12665-013-2218-1.

Gopinath, G., \& Seralathan, P. (2004). Identification of groundwater prospective zones using IRS-ID LISS III and pump test methods. Journal of the Indian Society of Remote Sensing, 32(4), 329-342. Available at: https://doi.org/10.1007/bfo3030858.

Jha, M. K., Chowdhury, A., Chowdary, V., \& Peiffer, S. (2007). Groundwater management and development by integrated remote sensing and geographic information systems: Prospects and constraints. Water Resources Management, 21(2), 427-467. Available at: https://doi.org/10.1007/s11269-006-9024-4.

József, T. (1999). Groundwater as a geologic agent: An overview of the causes, processes, and manifestations. Hydrogeology Journal, 7(1), 1-14. Available at: https://doi.org/10.1007/s100400050176.

Lahcen, Z., Gorini, C., Mania, J., Deffontaines, B., \& Zerouali, A. E. H. (2004). Spatial distribution of resistivity in the hydrogeological systems, and identification of the catchment area in the Rharb basin, Morocco. Hydrological Sciences Journal, 49(3), 387-398. Available at: https://doi.org/10.1623/hysj.49.3.387.54350. 
Machiwal, D., Rangi, N., \& Sharma, A. (2015). Integrated knowledge-and data-driven approaches for groundwater potential zoning using GIS and multi-criteria decision making techniques on hard-rock terrain of Ahar catchment, Rajasthan, India. Environmental Earth Sciences, 73(4), 1871-1892. Available at: https://doi.org/10.1007/s 12665-014-3544-7.

Mall, R. K., Gupta, A., Singh, R., Singh, R. S., \& Rathore, L. (2006). Water resources and climate change: An Indian perspective. Current Science, 90(12), 1610-1626.

Md Surabuddin, M., Pandey, A., \& Garg, R. (2008). Groundwater prospects evaluation based on hydrogeomorphological mapping using high resolution satellite images: A case study in Uttarakhand. Journal of the Indian Society of Remote Sensing, 36(1), 69-76. Available at: https://doi.org/10.1007/s12524-008-0007-1.

Murugesan, V., Krishnaraj, S., Kannusamy, V., Selvaraj, G., \& Subramanya, S. (2011). Groundwater potential zoning in Thirumanimuttar sub-basin Tamilnadu, India-A GIS and remote sensing approach. Geo-spatial Information Science, 14(1), 17-26. Available at: https://doi.org/10.1007/s11806-011-0422-2.

Nag, S., \& Ghosh, P. (2013). Delineation of groundwater potential zone in Chhatna Block, Bankura District, West Bengal, India using remote sensing and GIS techniques. Environmental earth sciences, 70(5), 2115-2127. Available at: https://doi.org/10.1007/s12665-012-1713-0.

Ramasamy, S. (1987). Morphotectonic evolution of east and west coasts of Indian Peninsular. Geological Survey of India. Spec. Pub. No. 24, 1989, 333 - 339 p. Arabian sea Seminar, Mangalore, 1987.

Ramasamy, S., Nagappan, N., \& Selvakumar, R. (2001). Fracture pattern modelling and groundwater hydrology in Hard Rock Aquifer System (pp. 280-291). Central Tamil Nadu, India: In: R.P. Singh and Vinod Tare, (Ed.), Spec. Vol. of the ISRS on Spatial Technology for Natural Hazards Management.

Sankar, K. (2002). Evaluation of groundwater potential zones using remote sensing data in Upper Vaigai river basin, Tamil Nadu, India. Journal of the Indian Society of Remote Sensing, 30(3), 119-129. Available at: https://doi.org/10.1007/bfo2990644.

Saraf, A., \& Choudhury, P. (1998). Integrated remote sensing and GIS for groundwater exploration and identification of artificial recharge sites. International Journal of Remote sensing, 19(10), 1825-1841. Available at: https://doi.org/10.1080/014311698215018.

Sikdar, P., Chakraborty, S., Adhya, E., \& Paul, P. (2004). Land use/land cover changes and groundwater potential zoning in and around Raniganj coal mining area, Bardhaman District, West Bengal-a GIS and remote sensing approach. Journal of Spatial Hydrology, 4(2), 1-24.

Sujarose, R., \& Krishnan, N. (2009). Spatial analysis of groundwater potential using remote sensing and GIS in the Kanyakumari and Nambiyar basins, India. Journal of the Indian Society of Remote Sensing, 37(4), 681-692. Available at: https://doi.org/10.1007/s 12524-009-0058-y.

Thirukumaran, V., Kumanan, C., \& Biswal, T. (2014). Geoinformatic modeling of groundwater resource mapping of Shear Zone regions-A case study on Attur Valley, Tamil Nadu, India. Journal of the Indian Society of Remote Sensing, 42(4), 789-800. Available at: https://doi.org/10.1007/s12524-014-0375-7.

Views and opinions expressed in this article are the views and opinions of the author(s), International Journal of Geography and Geology shall not be responsible or answerable for any loss, damage or liability etc. caused in relation to/arising out of the use of the content. 